Article

\title{
Awareness Training for Sustainable Development: Development, Implementation and Evaluation of a Mobile Application
}

\author{
Burcu Turan Çimşir ${ }^{1,2, *}$ and Hüseyin Uzunboylu ${ }^{1}$ \\ 1 Department of Computer and Instructional Technology, Near East University, Mersin 10, Turkey; \\ huseyin.uzunboylu@neu.edu.tr \\ 2 Department of Computer Technologies, Giresun University, Giresun 28200, Turkey \\ * Correspondence: burcu.turan@giresun.edu.tr; Tel.: +90-454-310-1471
}

Received: 5 December 2018; Accepted: 21 January 2019; Published: 24 January 2019

\begin{abstract}
In achieving sustainable development goals, every society and person has the responsibility to attempt to eliminate poverty, protect the environment, and ensure that all people live in peace and prosperity. In order to fulfill this responsibility, it is necessary to organize activities to support sustainable development goals. When the increasing daily use of mobile technologies in education is considered, it is thought that these technologies exhibit important potential in raising awareness for sustainable development goals. Thus, the aim of this study was to develop, implement and evaluate a mobile application for the awareness of university students about sustainable development goals. As a result of this research, the developed mobile application had a positive effect on university students' awareness of sustainable development goals, and students were glad to use the application.
\end{abstract}

Keywords: mobile technologies; mobile learning; mobile application; sustainable-development goals

\section{Introduction}

Sustainable development goals (SDGs) are a universal call by The United Nations to eradicate poverty, protect our planet, and ensure that all people live in peace and prosperity. SDGs comprise 17 interrelated goals [1]. Poverty has been a problem for every society in every period of human history. Nowadays, poverty is considered a global problem and is primarily understood as a humanitarian and social problem, rather than an economic problem. In today's world, where injustice is so globalized and poverty remains at a very high level, what is needed to reduce the problems caused by these two issues is an important question. In addition to the answers to that question, it is also important how willing and consistent people are at solving these problems [2]. While ending poverty and hunger, raising healthy individuals, quality education and decreasing inequalities are only a few of the United Nations Development Programme (UNDP 2030) targets, solving 17 problems to make the earth a habitable place is also among them. Since these problems are main global issues to discuss [3], every state, organization and individual has the responsibility to achieve sustainable development goals to solve them.

Awareness is defined as social groups and individuals' being conscious and sensitive towards the environment [4]. It is possible to increase awareness in terms of consciousness and sensibility-this directs individual behaviors [5]. When the previous studies are analyzed [6-8], it is seen that awareness education has a positive effect on various subjects such as information security, software development or water awareness. For this reason, whether awareness education is effective at increasing individuals' awareness of sustainable development goals (in terms of raising consciousness and sensibility) should be investigated. 
Currently, it is recommended to use technology in education to ensure effective learning [9]. Educational technology studies are directly influenced by innovations in information technology and focus on integrating these technologies into educational environments. When information technology (IT) is integrated with education, it attracts student attention and makes them more active during the learning process, enabling them to better understand the subject by increasing their motivation and engagement $[10,11]$. The developments in web technologies in today's information and communication society, where new-generation technologies are constantly replaced by newer ones, necessitate a more effective use of educational technologies in educational environments. Recently in this context, the use of mobile technologies has become widespread in the field of education as in many other fields.

The rapid growth of mobile technologies has the characteristics of what will hopefully be a learning revolution. Developments in mobile-communication technologies and the increase in smartphone sales, in which PDA features are integrated, supports of the current situation [12]. Studies showed that mobile learning that emerged with the use of mobile-communication technologies for the purpose of learning has advantages such as filling the time of students in different physical environments with activities related to learning, supporting group work in projects, and increasing communication and collaboration [13]. As a matter of fact, thanks to mobile learning and constructivist approaches, the concept of learning-independent of time and space-has gained importance. Thus, a new tendency appears that facilitates access to the information [14]. Mobile learning within this mentioned tendency refers to the usage of portable and usable digital mobile devices to facilitate and improve learning [15]. In addition, with mobile-learning materials, learners have the chance to benefit from learning environments for lifelong and unconscious learning, learning in times of need, conscious learning independent from time and place, so that the process becomes much easier [16]. To design mobile learning environments that are new and important, learners' perception and needs about those mobile-learning environments should be determined [17]. Thus, efficient learning environments should be designed in accordance with the perception and needs of the learners [18].

Information technology applications, such as mobile technologies, are a driving force in the education of sustainable development targets [19]. Moreover, UNESCO reported that information technology applications have an important role in facilitating the education of sustainable development goals [20]. When the studies conducted in this field are analyzed, it is seen that mobile technologies have the potential to facilitate the achievement sustainable development goals [21] thegoals.org project, a web page developed with mobile support, achieved success [22], and studies on sustainable development in universities are mostly theoretical or case studies [23]. While there is a large number of studies on sustainable development in the literature [24], most of these studies focus on a single target such as quality education, good health or gender equality [25-27]. However, since the goals of sustainable development are related to each other, it is considered that studies related to the use of mobile applications focusing on all objectives should be increased in terms of quality and quantity.

Throughout history, education has continuously pursued technology as a result of technological advances and has strived for the integration of technology into educational environments. As a result of educational technologies being a separate field, technology-supported education has started to be discussed more and how the technologies used affect the pedagogical structure in education has been discussed in many areas of education. For example, while some studies focus on how students' learning changes in technology-supported instruction [28-30], some studies attempt to show how student motivation increases in classes using technology [31,32]. Although the contribution of computers, internet or any technology in education is an undeniable fact, how these technologies are applied, rather than used, is also important, and this subject is in the interest of instructional technologies. The design of the teaching tool influences success much more than the technology used. The Clark-Kozma debate, known in the field of instructional technologies, has focused on this issue for years, and there are still some controversial discussions on this issue [33-38]. While Clark states that media is a tool that only transmits teaching and does not affect students' success to a significant degree, Kozma $[37,38]$ states that there is a high correlation between media and method, 
and the chosen media is important in the effectiveness of the method that will be used. Jonassen, Campbell and Davidson [39], Morrison [40], Reiser [41] and Shrock [42] stated that it is difficult to conclude this issue, that is, the media should be widely used in teaching and that it is important to use information technologies effectively. In his study, Wingkvist [43] also found a correlation between the development of information technologies and mobile learning and the innovations in information technologies are reflected on mobile learning methods. Maderia et al. [44] found that modular mobile learning environments that support student-centered and multimedia design principles support learning environments and play a complementary role. In their study, Chin and Jacobsson [22] introduced thegoals.org, a mobile-supported website for sustainable-development goals, and stated that the use of mobile technologies has an important role in achieving sustainable-development goals. Karatzoglou [23], who conducted a study on the contribution of universities to training on sustainable development, examined the published articles about sustainable-development goals in universities in 2003-2011. Karatzoglou stated that these articles were criticized, and studies on sustainable-development education were widely written as theoretical and case studies. Research was conducted by Bleck, Bullinger, Lude and Schaal in 2012 to determine the potential of mobile learning in environmental education for sustainable development [21]. As a result of the research, it has been stated that mobile learning has potential. Due to the benefits such as the opportunity of being used together with class activities, mobile learning enables outdoor activities and helps students to analyze their own content.

In summary, when considering the energy and creativity of future generations to find innovative solutions to seemingly difficult problems and progress in mobile technologies [45,46], researching previous scientific studies on the contributions of mobile technologies to sustainable-development education for university students are is a must. Therefore, in this study, the effects of mobile-assisted education on university-student awareness and their opinions on the targeted mobile application are evaluated in sustainable-development education, which includes targets for solving the problems mentioned above.

\subsection{Aim}

The aim of this study was to develop and implement an application for mobile-based sustainable-development goals, evaluate its effect on university students' awareness on the subject, and to identify the opinions of the students about the application.

For this purpose, the following research questions are answered:

1. Is there a significant difference between the pretest awareness level and the post-test level of the control group?

2. Is there a significant difference between the pretest awareness level and the post-test level of the experimental group?

3. Is there a significant difference between the post-test awareness level of the experimental group and the post-test awareness level of the control group?

4. What are the university students' perceptions and experiences related to the application?

\subsection{Limitations}

This study has the following limitations:

1. Sixty-two volunteer students studying at Giresun University. These students are enrolled in the education of sustainable development goals within the continuing education center of the same university and they volunteered to participate in the study.

2. Education on sustainable development goals and the content of UNDP SDG education conducted during the research period. The training content is provided by UNDP in open source format and all educators are encouraged to use it. 
3. The mobile application on sustainable development in terms of accessibility and the mobile application developed for 4G-supported iOS and Android-based devices.

4. The analysis of the qualitative and quantitative data collected during the six-week research process. The qualitative and quantitative data were analyzed, collected as a result of the six-week experience of the students.

\section{Materials and Methods}

\subsection{Research Model}

This is an experimental study and it was designed as a pre- and post-test research model including an experimental and a control group. The experimental and control groups were randomly formed. Those who used the sustainable-development mobile application during the process of sustainable-development education composed the experimental group, and those who did not composed the control group. The formal appearance of the research model and the meanings of the used symbols are presented in Table 1.

Table 1. Research design.

\begin{tabular}{ccccc}
\hline Group & Placement & Pretest & Independent Variable & Post-Test \\
\hline $\mathrm{G}_{\mathrm{E}}$ & $\mathrm{R}$ & $\mathrm{O}_{1}(\mathrm{i})$ & Mobile Supported Sustainable Development Training & $\mathrm{O}_{3}(\mathrm{i}), \mathrm{O}_{5}(\mathrm{~m})$ \\
$\mathrm{G}_{\mathrm{C}}$ & $\mathrm{R}$ & $\mathrm{O}_{2}(\mathrm{i})$ & Traditional Sustainable Development Training & $\mathrm{O}_{4}(\mathrm{i})$ \\
\hline
\end{tabular}

$\mathrm{G}_{\mathrm{E}}$ : Experimental Group; $\mathrm{G}_{\mathrm{C}}$ : Control Group; R: Random Placement; $\mathrm{O}_{1}(\mathrm{i})$ : Pretest for determining the awareness levels of the experimental group toward sustainable-development targets; $\mathrm{O}_{2}$ (i): Pretest for determining the awareness levels of the control group toward sustainable development targets; $\mathrm{O}_{3}$ (i): Post-test for determining the awareness levels of the experimental group toward sustainable development targets; $\mathrm{O}_{4}$ (i): Post-test for determining the awareness levels of the control group toward sustainable development targets; $\mathrm{O}_{5}(\mathrm{~m})$ : Questionnaire for determining the satisfaction levels of the experimental group about the sustainable-development mobile application.

\subsection{Study Group}

The study group consisted of 62 volunteer students who studied in various departments at Giresun University during the spring semester of academic year 2017-2018. For the participation of the students in the study, education on sustainable development goals was started within the Continuing Education and Research Center of the same university, and all the volunteers were allowed to participate in this education. The frequency values of the study group are given in Table 2.

Table 2. Frequency values of the study group.

\begin{tabular}{cccc}
\hline & Experimental & Control & Total \\
\hline $\mathrm{f}$ & 31 & 31 & 62 \\
\hline
\end{tabular}

The faculty or the college distribution of the study group is shown in Figure 1. When the students in the study group were examined based on the faculty or the college level, it was found that 28 students studied at a vocational school of higher education, 24 students at the faculty of education, six students at the faculty of economics and administrative sciences, and 4 students at the college of applied sciences. Thus, 34 students are in undergraduate programs and 28 are in associate degree programs. 


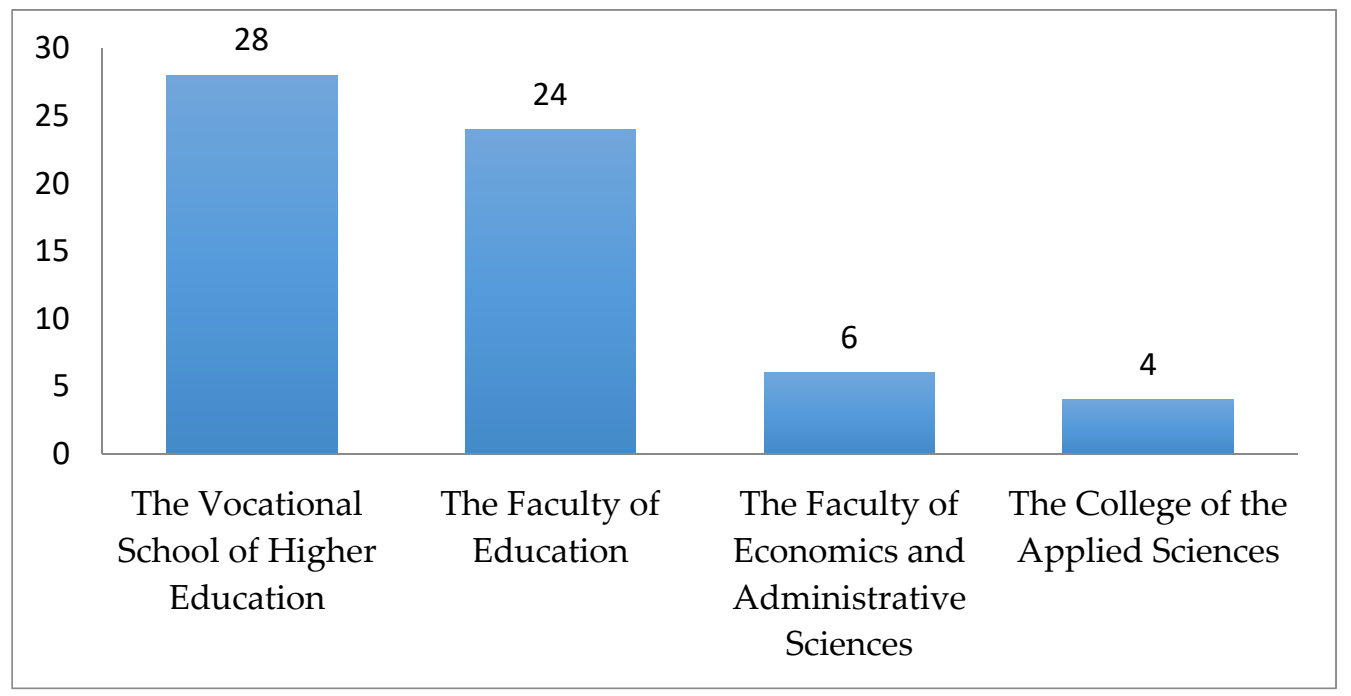

Figure 1. Faculty or college distribution of the study group.

Insignificant difference between the pretest scores of students' awareness of mobile internet, smartphone usage status, and sustainable-development goals was an effective factor in determining the experimental and control groups in the study. There was no significant difference between the pretest scores of the experimental and control groups, as shown in Table 3.

Table 3. Test analysis results of pretest scores of the control and experimental groups.

\begin{tabular}{lcccccc}
\hline \multicolumn{1}{c}{ Groups } & $\mathbf{N}$ & $\overline{\mathbf{x}}$ & $\mathbf{S}$ & $\mathbf{s d}$ & $\mathbf{t}$ & $\mathbf{P}$ \\
\hline Experimental & 31 & 39.6774 & 7.85870 & & & \\
Control & 31 & 40.1613 & 7.84473 & 10.99355 & -0.245 & 0.808 \\
\hline
\end{tabular}

\subsection{Method}

\subsubsection{Environment Preparation}

The Mobile-D model of Spataru [47] was used while developing the Sustainable Campus mobile application. According to this model, the application-development process starts with the scanning phase (Figure 2). At this stage, needed analysis is carried out. During the initial phase, planning and drafting studies are carried out based on the scanning studies, and the plans are implemented for the mobile application during the production phase. If the application is a complex structure, productions are combined during the integration phase. Then, its utility is evaluated and whether the mobile application meets needs by examining the system test and adjustments. Finally, by reflecting user feedback on the application, the final phase of the application is formed during the repair phase.

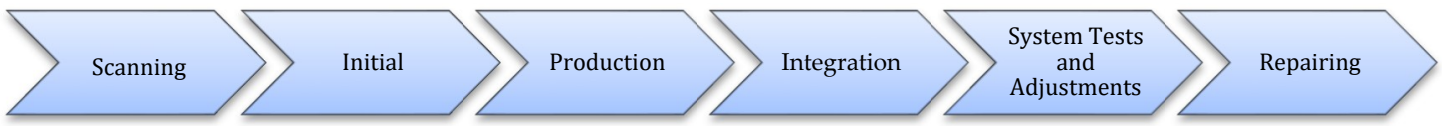

Figure 2. Phases of the Mobile D model based on mobile-application development.

The development of the mobile application began with the scanning stage of the Mobile D model. At this stage, user characteristics were observed and needed analysis was carried out. During the initial phase, which is the second phase of the study, planning and draft-development activities were carried out, and the production phase was started. XCode- and Android Studio-based platforms were used during the preparation of the application. In order to develop the mobile application, the web service client (management panel) that updates the database was activated to examine the new 
modules entered via the web interface on the mobile application. Then, the interface of the Sustainable Campus mobile application was designed and was updated after the management panel. YouTube, a video-sharing site, was integrated into the mobile application. Google Calendar, for students to have Access to planned activities, and the Firebase system that enables texting, were also placed in the application. After the integration of all these external tools, the content of other tools that have features such as collecting stars, taking photos, and taking notes was added and the application was tested. In the Mobile D model, the aim was to combine different production environments during the integration stage. After the installation of the mobile application to devices with a QR code reader, system tests and adjustments were carried out. After readjustments in terms of feedback, the mobile application was installed in Google Play and Android Store as "Sürdürülebilir Kampüs" (Sustainable Campus). The images of the latest version of the application are given in Figure 3.

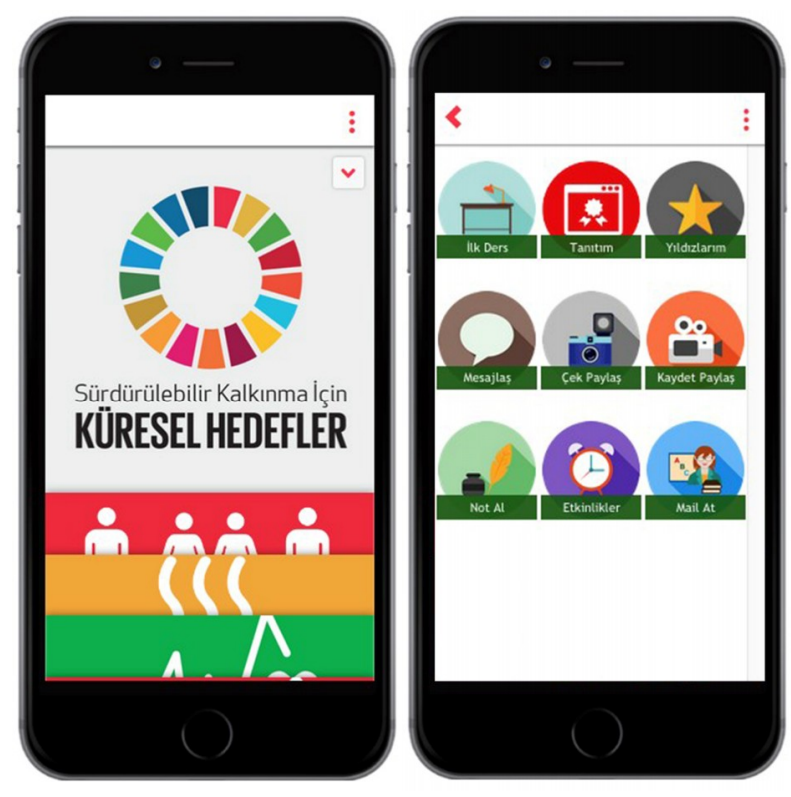

(a)

(b)

Figure 3. (a) Homepage screenshot of the Sustainable Campus application; (b) menu screenshot of the Sustainable Campus application.

\subsubsection{Data Collection}

The validity and reliability data study by the researchers was collected by the Sustainable Development Awareness Questionnaire, prepared in 2017, and by the "Questioning Form to Determine the Satisfaction Levels for the Sustainable Development Mobile Application". The Sustainable Development Awareness Questionnaire is five-point Likert scale consisting of 20 items, and its validity/reliability studies were conducted in March 2017. During its development, questions compiled from UNDP global goals education content were subjected to item analysis and items whose discrimination is 0.40 and above were tested. According to the statistical results, the Cronbach alpha value of the test whose items were reduced to 20, was calculated (Cronbach alpha $=0.917$ ). Additionally, the questionnaire was finalized after the evaluation of four field experts, one education expert and one language expert to ensure the content validity of the data collection tools. "Question Form for Determining Students Satisfaction Levels for Sustainable Development Mobile Application" consists of open-ended questions, and students completed this form by hand. The data obtained by using "The Questioning Form to Determine the Satisfaction Levels for the Sustainable Development Mobile Application" were analyzed by the researchers by separating the data based on themes by using descriptive analysis. 


\subsubsection{Implementation}

After the installation of the Sustainable Campus application in the App Store and Google Play application stores for the purpose of using it for education and increase university students' awareness about sustainable-development goals, the students in the experimental group were able to download the mobile application onto their mobile devices. The Global Goals training content, which provides access to everyone with traditional methods in the experimental and control groups, was implemented for six weeks. There were attempts to find solutions for problems of sustainable-development goals in education, with different goals being emphasized every week and students directed to develop different design ideas related to these goals. Thus, students in the control group were trained about sustainable-development goals with traditional education methods, while students in the experimental group were trained with mobile support in addition to traditional education. Since the control group did not need to have access to internet, whether the students had access to mobile internet was taken into consideration for the selection of students in the experimental and control groups. Besides, the information showing the similarities and differences between the experimental and control groups is given in Table 4.

Table 4. Similarities and differences between the experimental and control groups.

\begin{tabular}{ll}
\hline \multicolumn{1}{c}{ Similarities } & \multicolumn{1}{c}{ Differences } \\
\hline $\begin{array}{l}\text { Both groups participated in SDG education } \\
\text { with traditional teaching/learning } \\
\text { techniques. During the education providing } \\
\text { information about the 17 objectives, in-class } \\
\text { and out-of-class activities were conducted. }\end{array}$ & $\begin{array}{l}\text { The students in the experimental group used the mobile } \\
\text { application developed for SDG training as well as the } \\
\text { traditional learning method. Additionally, the students were } \\
\text { able to access information about the objectives from the mobile } \\
\text { application. }\end{array}$ \\
\hline $\begin{array}{l}\text { All students tried to develop new ideas to } \\
\text { achieve the objectives and to implement } \\
\text { those ideas. }\end{array}$ & $\begin{array}{l}\text { The students in the experimental group can communicate with } \\
\text { each other and their teachers, independent of time and space, } \\
\text { while developing their ideas. Also, with the help of the mobile } \\
\text { application, contents such as notes, images, and videos can be } \\
\text { created and shared on social networking sites. }\end{array}$ \\
\hline $\begin{array}{l}\text { All students can be informed about activities } \\
\text { related to the goals within the university. }\end{array}$ & $\begin{array}{l}\text { While the students in the control group can be informed about } \\
\text { these events with the help of the bulletin board, the students in } \\
\text { the experimental group can access this information from } \\
\text { anywhere with the help of the mobile application. }\end{array}$ \\
\hline
\end{tabular}

Unlike the control group, the students in the experimental group used the mobile application to obtain access to the global goals education content, independent of time and space, as well as many other features provided by the application. The first of those features is to perform the collecting stars task as part of gamification by performing the tasks assigned to them. In this way, the aim is that the students will win stars by performing activities on the SDG issues and taking initiatives to benefit the world. Students can communicate with their friends and teachers on this mobile application while performing these activities. They can also create videos or images and share them on social networks to provide links to content regarding their goals, so even non-knowledgeable connections are expected to be made aware of the goals. In addition, the aim is to facilitate students' awareness of activities such as seminars and panels related to the 17 goals within the university by using the activities section of the mobile application. Training images of the control and experimental groups are presented in Figure 4 . The training images of the control and experimental groups are given in Figure 4. 


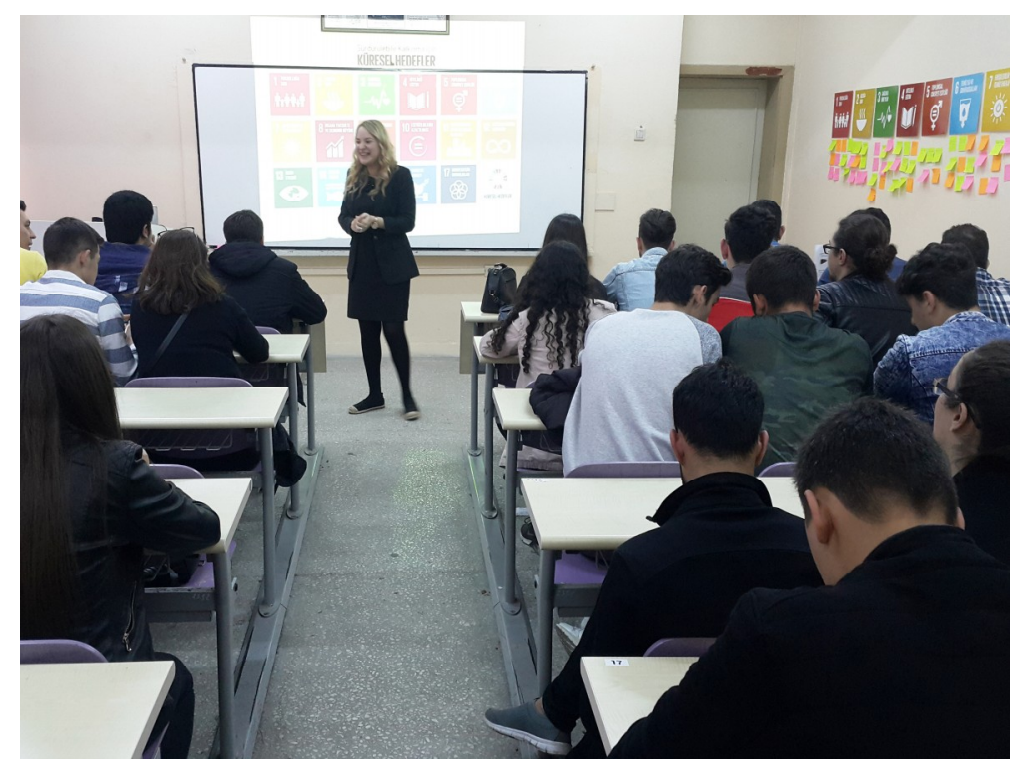

(a)

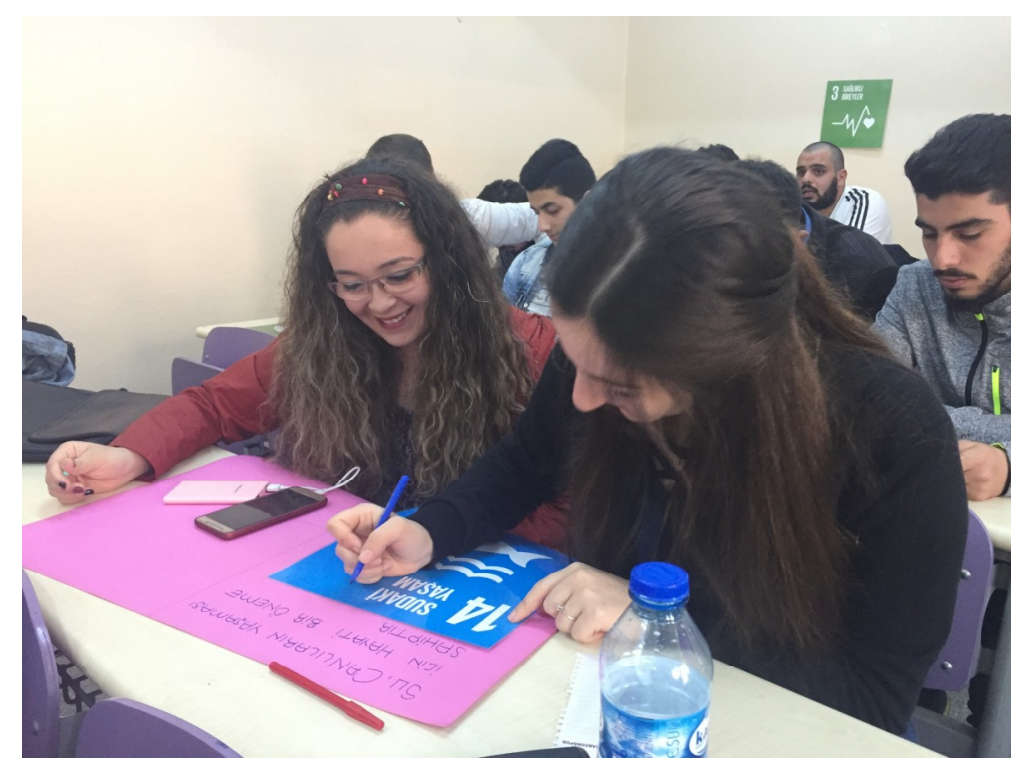

(b)

Figure 4. (a) Sample image from the sustainable development goal (SDG) training of the control group; (b) sample image from the SDG training of the experimental group.

In order to address targets such as climate action and life on land, seedlings were given to the students and planting activities were carried out (Figure 5). At the end of the six weeks, education certificates were distributed to the students who participated in the training about awareness for the sustainable-development goals. 


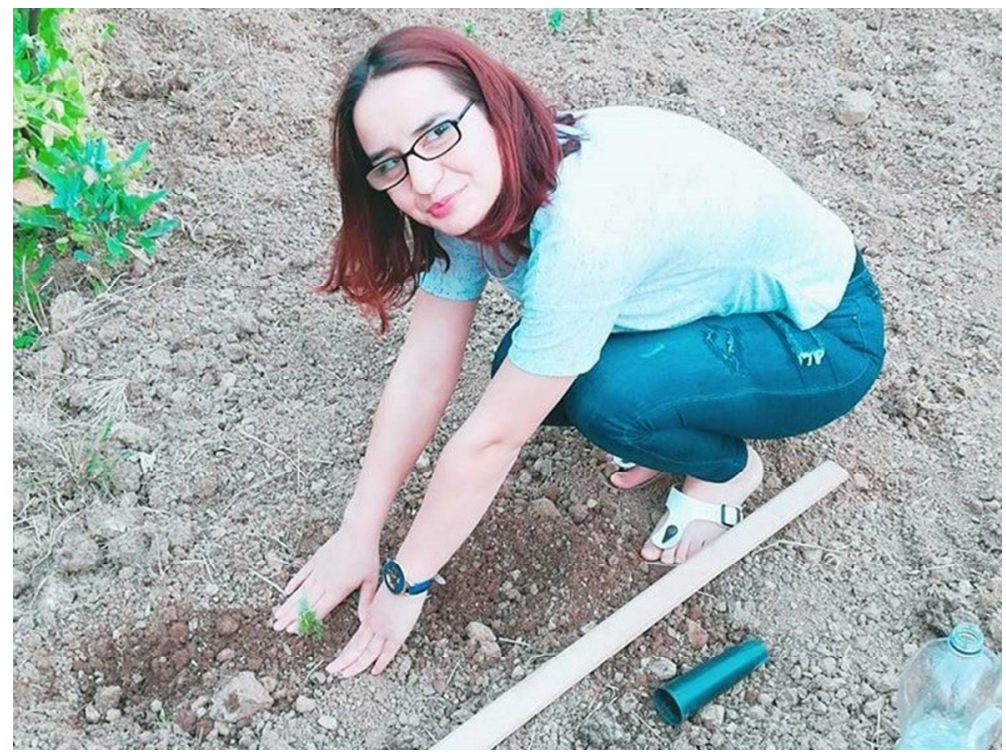

(a)

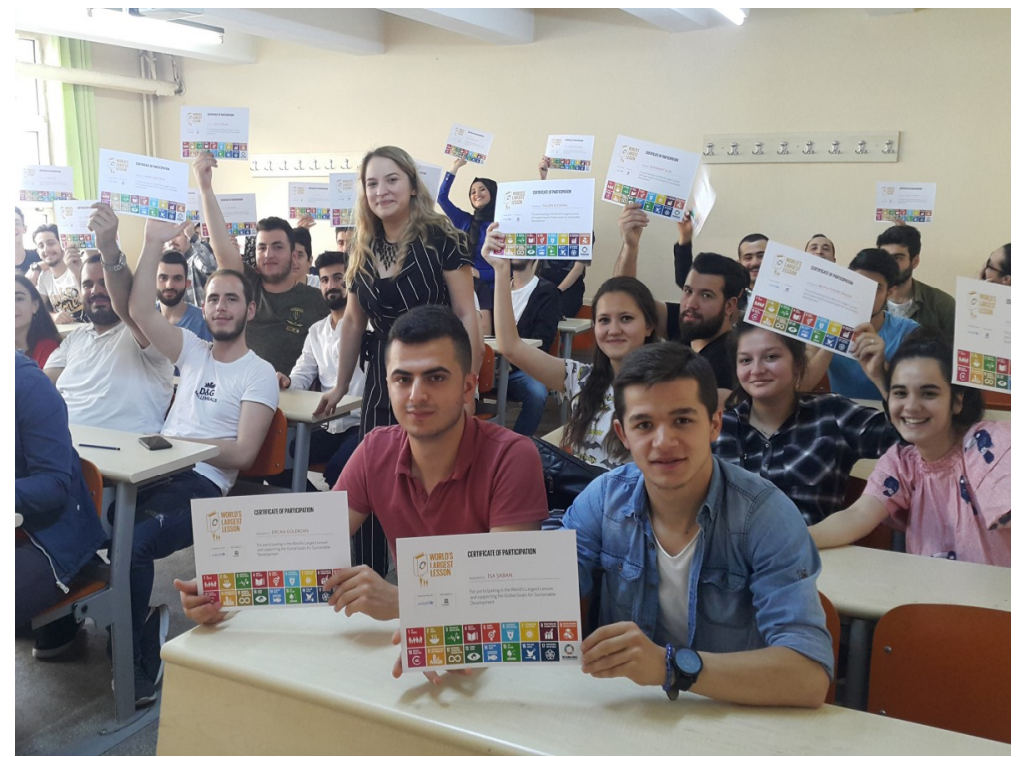

(b)

Figure 5. (a) Sample image from the planting activities; (b) sample image from the certificate ceremony.

\section{Results}

This section presents the findings related to the research questions of the research. The first research question of the study is whether there was significant difference between the pretest and post-test awareness level of the control group. The findings obtained from this research question are presented in Table 5.

Table 5. T-test analysis results of pretest and post-test scores of the control group.

\begin{tabular}{ccccccc}
\hline Groups & $\mathbf{N}$ & $\overline{\mathbf{x}}$ & $\mathbf{S}$ & $\mathbf{s d}$ & $\mathbf{t}$ & $\boldsymbol{p}$ \\
\hline Control Pretest & 31 & 40.1613 & 7.84473 & & & \\
\cline { 1 - 5 } Control Post-test & 31 & 80.9677 & 7.13902 & & & \\
\hline
\end{tabular}


When the pre- and post-test results of the control group, for which traditional teaching method was applied, were examined, as shown in Table 5, it could be seen that the pretest arithmetic mean of the control group was $\bar{x}=40.1613$ and the post-test arithmetic mean increased to $\bar{x}=80.9677$. As the result of the $t$-test carried out to find out whether the difference between the means was significant or not, it was found that it was significant $(\mathrm{t}=-39.775, p<0.05)$. Consequently, an increase in the achievement of students in the control group, for whom traditional teaching method was applied, was observed.

The second research question of the research was whether there was a significant difference between the pre- and post-test awareness level of the experimental group. The findings obtained from this research question are presented in Table 6.

Table 6. T-test analysis results of the pre-test scores of the experimental group.

\begin{tabular}{ccccccc}
\hline Groups & $\mathbf{N}$ & $\overline{\mathbf{x}}$ & $\mathbf{S}$ & $\mathbf{s d}$ & $\mathbf{t}$ & $\boldsymbol{p}$ \\
\cline { 1 - 5 } Experimental Pretest & 31 & 39.6774 & 7.85870 & & & \\
\cline { 1 - 5 } Experimental Post-test & 31 & 89.0323 & 6.18322 & & & \\
\hline
\end{tabular}

When the pre- and post-test awareness levels of students in the experimental group that took part in the training about mobile-supported sustainable-development goals were analyzed, as seen in Table 6, it could be seen that the pretest mean of the experimental group was $\bar{x}=39.6774$ and the post-test mean was $\bar{x}=89.0323$. This difference was meaningful $(t=-49.168, p<0.05)$. In this case, it could be concluded that the use of mobile technologies in education about sustainable-development goals is effective in raising the awareness of university students. As a result of the $t$-test carried out to find out whether the difference between the means was significant or not, it was found that the difference as significant $(t=-49.168, p<0.05)$. Thus, it could be concluded that the use of mobile technologies in the education of sustainable-development goals is effective in raising the awareness of university students.

The third research question of the study was whether there was a significant difference between the post-test awareness level of the experimental group and the post-test awareness level of the control group. The findings of this research question are presented in Table 7.

Table 7. T-test analysis results of the post-test scores of the experimental and control groups.

\begin{tabular}{ccccccc}
\hline Groups & $\mathbf{N}$ & $\overline{\mathbf{x}}$ & $\mathbf{S}$ & $\mathbf{s d}$ & $\mathbf{t}$ & $\boldsymbol{p}$ \\
\hline Experimental Post-test & 31 & 89.0323 & 6.18322 & & & \\
\cline { 1 - 5 } Control Post-test & 31 & 80.9677 & 7.13902 & & & \\
\hline
\end{tabular}

When the post-test awareness levels of the experimental and control groups were examined, as seen from Table 7 , the arithmetic mean of the experimental group $(\bar{x}=89.0323)$ was analyzed and seen that it was more than the arithmetic mean of the control group $(\bar{x}=80.9677)$. As the result of $t$-test carried out to find out whether the difference between the means was significant or not, it was found that the difference was significant $(\mathrm{t}=4.507, p<0.05)$. Based on these results, it might be said that the use of mobile technologies in sustainable development goals education, as carried out in this research, has an impact on university students' awareness.

The last research question of the research was what the perceptions and experiences of the university students related to the developed application were, and the findings of the question are presented in the headings.

Question 1: "You have participated in the study of the implementation of mobile-supported sustainable-development goals. To what extent does this application meet your expectations?" The students' answers to Question 1 are presented in Table 8. 
Table 8. Analysis results of students' answers to Question 1.

\begin{tabular}{|c|c|}
\hline f & Answer \\
\hline 23 & $\begin{array}{l}\text { The application was above my expectation because it provided me with information about sustainable } \\
\text { development goals. }\end{array}$ \\
\hline 9 & The application met my expectation as it supported me in becoming a person conscious of the 17 goals. \\
\hline 7 & Mobile support to participate in the application increased my interest in learning about the goals. \\
\hline 5 & I feel lucky to be involved in this practice. \\
\hline 4 & $\begin{array}{l}\text { Throughout the study, I found the activities that were carried out to raise awareness about the goals with } \\
\text { friends fun and beneficial. }\end{array}$ \\
\hline
\end{tabular}

Twenty-three of the students who participated in the study stated that the application was above their expectations to obtain information about the sustainable-development goals, nine of them stated that the application was effective to becoming a conscious person, seven of them stated that the application increased their interest in learning about mobile support for sustainable-development goals, five of them stated that they felt lucky to be a part of this implementation, and four of them stated that the activities to raise awareness of sustainable development goals were fun and beneficial.

Question 2: "How were your experiences during the use of the mobile application?" The answers of the students for Question 2 are presented in Table 9.

Table 9. Analysis results of students' answers to Question 2.

\begin{tabular}{cl}
\hline $\mathbf{f}$ & \multicolumn{1}{c}{ Answer } \\
\hline $\mathbf{2 6}$ & I've been informed about the SDGs through this application. \\
$\mathbf{1 0}$ & I am glad to use this application. \\
$\mathbf{3}$ & I did not experience any difficulty while using the application. Only the slowdowns caused by the \\
$\mathbf{3}$ & internet connection made the application difficult to use. \\
\hline & I was interested in using technology while doing activities that would make the world beautiful. \\
\hline
\end{tabular}

When students were asked about their experiences of using the mobile application during the research, 26 of the students said that they were informed about the sustainable-development goals through the mobile application, 10 of them stated that they were happy to use the mobile application, three of them stated that they found the application easy but slowdowns could happen due to their internet connection, and the other three participants stated that they were interested in taking part in activities that are going to help save the world via technology.

Question 3: "What are your opinions on the interface design of the mobile application for sustainable-development goals?" The students' answers to Question 3 are presented in Table 10.

Table 10. Analysis results of students' answers to Question 3.

\begin{tabular}{cl}
\hline $\mathbf{f}$ & Answer \\
\hline $\mathbf{2 9}$ & The mobile application had a simple and apparent interface. \\
$\mathbf{6}$ & The icons on the mobile application's menu screen were designed to be suitable for its purpose. \\
$\mathbf{5}$ & The colors used in the interface design of the mobile application were suitable for its purpose. \\
$\mathbf{2}$ & The interface of the mobile application could be developed. \\
\hline
\end{tabular}

On the interface design of the mobile application, most students stated that the application had a simple and clear interface. Six students stated that the icons of the mobile application were suitable for the purpose of the application, five students stated that the colors used on the application were suitable for the purpose of the application, and two students said that the interface of the mobile application could be improved. 
Question 4: "What are your opinions on the visual and audio materials of the mobile application for sustainable-development goals?" The students' answers for Question 4 are presented in Table 11.

Table 11. Analysis results of students' answers to Question 4.

\begin{tabular}{cl}
\hline $\mathbf{f}$ & Answer \\
\hline $\mathbf{2 6}$ & The visual elements of the application were professionally prepared. \\
$\mathbf{2 0}$ & The auditory elements of the application were comprehensible. \\
$\mathbf{3}$ & More visual and audio materials could be added to the application. \\
\hline
\end{tabular}

Twenty-six of the students stated that the visual materials of the application were prepared professionally, 20 of them said that the auditory elements of the application were comprehensible, and three of them said that more visual and audio material could be added to the application.

Question 5: "How effective do you think the mobile application was for your awareness of sustainable-development goals?" Students' answers to Question 5 are presented in Table 12.

Table 12. Analysis results of students' answers to Question 5.

\begin{tabular}{cl}
\hline $\mathbf{f}$ & \multicolumn{1}{c}{ Answer } \\
\hline $\mathbf{2 5}$ & $\begin{array}{l}\text { I am pleased that I have access to information about sustainable-development goals everywhere. } \\
\text { Taking notes, being informed about events, and being able to share on social networks via the mobile } \\
\mathbf{1 5}\end{array}$ \\
$\begin{array}{l}\text { application played an important role in gaining awareness. } \\
\text { The mobile application was an effective tool for me to communicate with my friends while saving the } \\
\text { world. }\end{array}$ \\
\hline
\end{tabular}

Twenty-five of the students who participated in the research stated that they were pleased to be able to access the information related to sustainable development regardless of time and place. Fifteen of them stated that being informed about events and being able to share them on social networks via their mobile phone had a significant role in raising awareness, and five of them stated that the mobile application was effective in being in communication with friends while participating in activities to save the world.

Question 6: "What do you think about your interaction with your friends and teachers on the mobile application for sustainable-development goals?" Students' answers to Question 6 are presented in Table 13.

Table 13. Analysis results of students' answers to Question 6.

\begin{tabular}{|c|c|}
\hline 4 & Answer \\
\hline 15 & I was pleased to be able to communicate with my instructors via the mobile application. \\
\hline 6 & $\begin{array}{l}\text { During the education of sustainable-development goals, the role of gamification in the mobile } \\
\text { application for my communication with my friends was very important. }\end{array}$ \\
\hline 4 & The messaging section of the mobile application was enough to communicate with my friends. \\
\hline 3 & $\begin{array}{l}\text { Through the take-photo-and-share section in the mobile application, sharing photos and videos } \\
\text { during SDG training increased my interaction with my friends. }\end{array}$ \\
\hline 3 & I abstained from communicating with other participants using the application. \\
\hline
\end{tabular}

Fifteen of the students who participated in the application said that they were contented to communicate with their teachers through the application, six of them stated that their communication with their friends during the training for sustainable development goals had an impact on the gamification section, four of them said that it had an impact on the messaging section, and three of them stated that it had an impact on the take-photo-and-share section. In addition, three of the 
students who participated in the study stated that they abstained from communicating with their friends via the mobile application.

Question 7: "What are your opinions on the gamification (star) activities in the mobile application for sustainable-development goals?" Students' answers to Question 7 are presented in Table 14.

Table 14. Analysis results of students' answers to Question 7.

\begin{tabular}{cl}
\hline $\mathbf{f}$ & \multicolumn{1}{c}{ Answer } \\
\hline $\mathbf{2 0}$ & I am pleased to feel that I have done beneficial things for the community through the activities we \\
$\mathbf{1 2}$ & performed with the gamification activities. \\
$\mathbf{8}$ & I increased my communication with my friends through the gamification activities. \\
$\mathbf{2}$ & I never used the gamification activities. \\
\hline
\end{tabular}

Twenty of the students participating in the study stated that they were pleased to do beneficial things for the community through gamification activities such as planting, 12 of them stated that the gamification activities in the mobile application increased the communication with their friends, eight of them said that competing with their friends increased their interest in learning and two of them stated that they never used the gamification activities in the mobile application.

Question 8: "What are your suggestions on the development of the mobile application for sustainable-development goals?" Students' answers to Question 8 are presented in Table 15.

Table 15. Analysis results of students' answers to Question 8.

\begin{tabular}{cl}
\hline $\mathbf{f}$ & \multicolumn{1}{c}{ Answer } \\
\hline $\mathbf{2 2}$ & The application could be translated into different languages. \\
$\mathbf{8}$ & Similar practices related to SDGs could be extended to all levels of education. \\
$\mathbf{7}$ & It could be converted into an application that does not require an internet connection. \\
$\mathbf{2}$ & Notifications giving us duties could be sent. \\
\hline
\end{tabular}
$\mathrm{N}=31$.

Twenty-two of the university students who used the mobile application stated that the application could be translated into different languages, eight of them stated that similar practices related to SDGs could be extended to all levels of education, seven of them stated that it could be converted into an application that does not need an internet connection and two of them said that notifications with sustainable-development goals could be periodically sent to students.

\section{Discussion}

The basic objective of mobile applications developed for university students' sustainable development goals education is not only the use of technology, but also the use of the application and its benefit for the students. These study results can be said to be in parallel with the research conducted by Madeira et al. [44] because it was supportively observed in these study results that mobile technologies had an impact on students' awareness during sustainable development goals education. Therefore, based on these findings, it can be suggested to use mobile applications as support for the traditional teaching method in sustainable development goals education. It is also believed that mobile applications should be developed in such a way as to enable in-class and out-of-class activities.

The sustainable campus mobile application, developed for this research, supports the study results of Bleck, Bullinger, Lude and Schaal [21] because this application can be used in combination with class activities and enables outdoor activities; students can create and share their own content and at the end of the implementation, it influences students' awareness level. Since most of the students are satisfied to be in contact with their friends and teachers during sustainable development goals 
education, it might be suggested to add new sections such as messaging, mail or social networks on the applications developed. Based on the students' suggestions on the development of mobile applications, mobile applications can be designed to enable progressive development at successive grade levels in the future, and different language options can be added; this might allow more students to use applications. Researchers who want to develop similar applications for sustainable development goals education might develop applications that are appropriate for the mobile application development model such as Mobile D by using Swift, Xcode for iOS; Android Studio or other helpful software for Android. Moreover, the application development process can be integrated into the course, and design-based studies in which students have a role in development can be carried out. Researchers or students can access visual and educational materials such as logos, icons, etc., that they need for developing applications from the website, "World's Largest Lesson" [48]. With those materials, they can develop mobile learning applications for any sustainable development goal they want. Considering the contribution of mobile technologies to education on sustainable development and the lack of experimental studies in the field, it could be said that, in order to achieve sustainable-development goals, it is necessary to increase the quantity and quality of the studies, which supports the research results presented here. Furthermore, evaluating teachers' views on the use of mobile applications in sustainable development goals education might be considered as a future research direction.

\section{Conclusions}

The application developed during this study has scientific and social content, instant notifications, and a user-based gamification mechanism related to sustainable-development targets for iOS and Android operating-system users. The teaching content of the application includes open-source educational materials distributed by UNDP and it is enriched with the notification, communication, social network support and gamification content of mobile technologies. Many of the university students who used the application stated that they were happy to do so, and that the application served its purpose and met their needs well. It could be concluded that the students participating in the study stated that they were contented to take part in world-saving activities like planting trees while sitting at home; therefore, this shows that it is not so difficult to raise awareness about sustainable development goals by using the right educational technologies and training techniques. A remarkable conclusion from the research findings is that university students are pleased to carry out activities that are beneficial to society, such as planting trees or sharing information on sustainable development goals with the help of social networks on a mobile application. Also, students state that the social networks and gamification part of the mobile application is effective at increasing interaction with other students, and the part that enables students to send an e-mail to instructors is effective at increasing interaction with instructors. Based on this, teachers can integrate activities about socially beneficial sustainable development goals into their lessons and support students by using this and similar mobile learning practices. However, the importance of internet speed should not be ignored since a connection with the server in the mobile application happens online. If there is no internet connection or it is at low speed, a user would not be able to contact the server and interact with the mobile application. These points show the weak aspects of the application. Based on the research results, it is suggested to researchers who will develop applications for future sustainable development goals education that mobile learning tools can work without an internet connection; they can be used at all teaching levels and can have different language options.

Regardless of the research results, it is thought that students' knowledge about sustainable development goals can have an impact on achieving the 2030 goals determined by UNDP. Therefore, the participation of researchers and educators who are not aware of the objectives in the instructive programme "Microsoft Education Teaching Sustainable Development Goals", which is offered free of charge, is recommended in order to reach more students. Researchers could develop and evaluate mobile learning content for people who cannot physically attend the school, and develop learning content on health care, security, etc., for farmers in rural areas by using the benefits of mobile devices. 
In addition, the necessity for an increase in the activities related to the goals was found to be very significant. The fact that publications related to sustainable development are regularly produced and are increasing could contribute to raising awareness on sustainable development.

Author Contributions: Conceptualization, B.T.Ç. and H.U.; methodology, B.T.Ç.; software, B.T.Ç.; validation, B.T.Ç. and H.U.; formal analysis, B.T.Ç. and H.U.; investigation, H.U.; resources, B.T.Ç.; data curation, H.U.; writing—original draft preparation, B.T.Ç.; writing—review and editing, B.T.Ç. and H.U.; supervision, H.U.

Funding: This research received no external funding.

Acknowledgments: For his quick and helpful answers, we thank the editor and all reviewers for their contribution to the manuscript.

Conflicts of Interest: The authors declare no conflicts of interest.

\section{References}

1. UNDP. Sürdürülebilir Kalkınma Hedefleri. Available online: http://www.tr.undp.org/content/turkey/tr/ home/sustainable-development-goals.html (accessed on 9 August 2018).

2. Emin, E. Global Injustice: World Poverty and Inequality Report. Available online: https:/ /www.academia. edu/29989458/D\%C3\%BCnya_Yoksulluk_ve_E\%C5\%9Fitsizlik_Raporu (accessed on 24 January 2019).

3. Unesco. Available online: http://unesco.org.tr/dokumanlar/duyurular/skh.pdf (accessed on 17 August 2018).

4. Keleş, Ö. Application and Evaluation of Ecological Footprint as an Environmental Education Tool towards Sustainable. Ph.D. Thesis, Gazi University, Ankara, Turkey, 2007.

5. Engin, E.; Çam, O. Self-awareness and psychiatric nursing. J. Ege Univ. Nurs. Fac. 2005, 21, 159-168.

6. Şahinaslan, E.; Kandemir, R.; Şahinaslan, Ö. Sample of information security education awareness. In Proceedings of the XI. Academic Informatics Conference, Şanlıurfa, Turkey, 11-13 February 2009.

7. Inal, Y.; Çağıltay, N.E. Engineer candidates' software development awareness for disabled users. In Proceedings of the 34. TBD National Informatics Symposium, Ankara, Turkey, 20-21 December 2017.

8. Ergin, Ö. An Education Project on Water Awareness; Tmmob 2; Water Policies Congress: Ankara, Turkey, 2008.

9. Seferoğlu, S.S. The Use of Technology in Primary Schools and the Perspectives of Managers; Academic Computing: Şanliurfa, Turkey, 2009.

10. Kreijns, K.; Acker, F.V.; Vermeulen, M.; Buuren, H.V. What stimulates teachers to integrate ICT in their pedagogical practices? The use of digital learning materials in education. Comput. Hum. Behav. 2013, 29, 217-225. [CrossRef]

11. Shen, C.X.; Liu, R.D.; Wang, D. Why are children attracted to the Internet? The role of need satisfaction perceived online and perceived in daily real life. Comput. Hum. Behav. 2013, 29, 185-192. [CrossRef]

12. Trifonova, A.; Ronchetti, M. Where is mobile learning going. In Proceedings of the World Conference on E-Learning in Corporate, Government, Healthcare, and Higher Education, Phoenix, AZ, USA, 7-11 November 2003; pp. 1794-1801.

13. Gay, G.; Stefanone, M.; Grace-Martin, M.; Hembrooke, H. The effects of wireless computing in collaborative learning environments. Int. J. Hum.-Comput. Interact. 2001, 13, 257-276. [CrossRef]

14. Küçük, S.; Kapakin, S.; Göktaş, Y. Learning anatomy via mobile augmented reality: Effects on achievement and cognitive load. Anat. Sci. Educ. 2016, 9, 411-421.

15. O'Connell, M.; Smith, J. A Guide to Working with Mlearning Standards: A Manual for Teachers Trainers and Developers; Australian Flexible Learning Network: Sydney, Australia, 2007.

16. Bulun, M.; Gülnar, B.; Güran, S. Mobile Technologies in Education. Turk. Online J. Educ. Technol 2004, 3, 23.

17. Menzi, N.; Nezih, Ö.; Çalışkan, E. Investigating educational researchers' views of using mobile technologies for educational purposes based on technology acceptance model. Ege J. Educ. 2012, 13, 40-55.

18. Elçiçek, M.; Bahçeci, F. The research of the vocational school student's attitudes towards mobile learning. Sakarya Univ. J. Educ. Fac. 2015, 30, 17-33.

19. Rogers-Estable, M. Technology \& Sustainable Development: How Online Tools Can Educate. Available online: https:/ / www.sustainabilityprofessionals.org/sites/default/files/Technology_and_ESD. pdf (accessed on 21 January 2019). 
20. Wagner, D.A.; Day, B.; James, T.; Kozma, R.B.; Miller, J.; Unwin, T. Monitoring and Evaluation of ICT in Education Projects: A Handbook for Developing Countries; Infodev/World Bank: Washington, DC, USA, 2005; Available online: http:/ /www.infodev.org/en/Document.9.pdf (accessed on 27 December 2018).

21. Bleck, S.; Bullinger, M.; Lude, A.; Schaal, S. Electronic mobile devices in environmental education (EE) and education for sustainable development (ESD)-Evaluation of concepts and potentials. Procedia-Soc. Behav. Sci. 2012, 46, 1232-1236.

22. Chin, A.; Jacobsson, T. TheGoals.org: Mobile global education on the Sustainable Development Goals. J. Clean. Prod. 2016, 123, 227-229.

23. Karatzoglou, B. An in-depth literature review of the evolving roles and contributions of universities to education for sustainable development. J. Clean. Prod. 2013, 49, 44-53.

24. Çelik, Y. Concept of sustainable development and health. Hacet. Univ. Health Admin. J. 2014, 9, $19-37$.

25. Velázquez, F.D.C.; Méndez, G.M. Augmented reality and mobile devices: A binominal methodological resource for inclusive education (SDG 4). An Example in Secondary Education. Sustainability 2018, 10, 3446. [CrossRef]

26. Iribarren, S.J.; Schnall, R. mHealth: The intersection of mobile technology and health. In Health Informatics-E-Book: An Interprofessional Approach; Mosby: St Louis, MO, USA, 2016; p. 255.

27. Crompton, H. How mobile learning initiatives can empower women. Int. Women Online J. Distance Educ. 2017, 6, 2.

28. Cohen, D.K. 11 Educational technology and school organization. Technol. Educ. Look. Toward 2020, $1988,231$.

29. Council, N.R. National Science Education Standards; National Academy Press: Washington, DC, USA, 1988.

30. Kozma, R.B. Technology and classroom practices: An international study. J. Res. Technol. Educ. 2003, 36, 1-14. [CrossRef]

31. Mistler-Jackson, M.; Butler Songer, N. Student motivation and internet technology: Are students empowered to learn science? J. Res. Sci. Teach. 2000, 37, 459-479. [CrossRef]

32. Susskind, J.E. PowerPoint's power in the classroom: Enhancing students' self-efficacy and attitudes. Comput. Educ. 2005, 45, 203-215.

33. Clark, R.E. Reconsidering research on learning from media. Rev. Educ. Res. 1983, 53, 445-459.

34. Clark, R.E. Media and method. Educ. Technol. Res. Dev. 1994, 42, 7-10.

35. Clark, R.E. Media will never influence learning. Educ. Technol. Res. Dev. 1994, 42, 21-29. [CrossRef]

36. Clark, R.E. What is next in the media and methods debate. In Learning from Media: Argument, Analysis, and Evidence; Information Age Publishing: Scottsdale, AZ, USA.

37. Kozma, R.B. Learning with media. Rev. Educ. Res. 1991, 61, 179-211.

38. Kozma, R.B. Will media influence learning? Reframing the debate. Educ. Technol. Res. Dev. 1994, 42, 7-19.

39. Jonassen, D.H.; Campbell, J.P.; Davidson, M.E. Learning with media: Restructuring the debate. Educ. Technol. Res. Dev. 1994, 42, 31-39.

40. Morrison, G.R. The media effects question: "Unresolvable" or asking the right question. Educ. Technol. Res. Dev. 1994, 42, 41-44. [CrossRef]

41. Reiser, R.A. Clark's invitation to the dance: An instructional designer's response. Educ. Technol. Res. Dev. 1994, 42, 45-48.

42. Shrock, S.A. The media influence debate: Read the fine print, but don't lose sight of the big picture. Educ. Technol. Res. Dev. 1994, 42, 49-53. [CrossRef]

43. Wingkvist, A. Understanding Scalability and Sustainability in Mobile Learning: A Systems Development Framework; Växjö University Press: Kalmar, Sweden; Växjö, Sweden, 2009.

44. Madeira, R.N.; Pires, V.; Dias, O.P.; Martins, J. An analog electronics mobile course with a competitive learning approach. Int. J. Interact. Mob. Technol. 2010, 4, 37-44. [CrossRef]

45. Ar1, A. An analysis of the relationship between the economic growth and unemployment in Turkey: A new cointegration. Test. Res. J. Politics Econ. Manag 2016, 4, 57-67. Available online: http://www. siyasetekonomiyonetim.org/index.php/seyad/article/viewFile/412/272 (accessed on 24 January 2019).

46. Human Development Report 1999. Available online: http://www.tr.undp.org/content/turkey/tr/home/ library/national-hdrs/nhdr1999.html (accessed on 15 August 2018). 
47. Spataru, A.C. Agile Development Methods for Mobile Applications. Master's Thesis, Computer Science School of Informatics, University of Edinburgh, Edinburgh, UK, 2010.

48. World's Largest Lesson. Available online: http://worldslargestlesson.globalgoals.org/ (accessed on 17 January 2019).

(c) 2019 by the authors. Licensee MDPI, Basel, Switzerland. This article is an open access article distributed under the terms and conditions of the Creative Commons Attribution (CC BY) license (http:/ / creativecommons.org/licenses/by/4.0/). 